\title{
Protoporphyrin IX Extraction from Quail Eggshell (Cortunix cortunix) and Its Complexity with Zn(II)
}

\section{Ekstraksi Protoporfirin IX dari Kerabang Telur Puyuh (Cortunix cortunix) dan Kompleksasinya dengan $\mathrm{Zn}$ (II)}

\author{
A. Rindang Anggit Laksono ${ }^{\text {a,* }}$, Yohanes Martono ${ }^{a}$, Cucun Alep Riyanto ${ }^{a}$ \\ ${ }^{a}$ Program Studi Kimia, Fakultas Sains dan Matematika, Universitas Kristen Satya \\ Wacana, \\ *email : 652014002@student.uksw.edu
}

\begin{abstract}
The aim of this research is to find the optimal condition for $Z n(I I)$ complexation with protoporphyrin IX which is a natural coloring pigment on quail eggshell. The concentration of protoporphyrin IX extract is $0.01 \%(w / w)$ of the dried extract. The results of the complex are analyzed using Response Surface Methodology (RSM). The design used was central composite design with 3 factor variables $X_{1}=p H(2 ; 4 ; 6), X_{2}$ $=$ ratios $(1: 3,1: 4,1: 5)$ and $X_{3}=$ time $\left(30^{\prime}, 60^{\prime}, 90^{\prime}\right)$. The modeling used is linear and shows that the $\mathrm{pH}$, ratio, and time factor have an influence on the complexation. This model gives the absorbance equation $Y=2.12506$ - 0.049856X1 - 020316X2 $0,00409857 X 3$ and gives treatment in the most optimum complexation of $\mathrm{pH} \mathrm{2;} \mathrm{ratio} \mathrm{of}$ 1: 3; and time for 30 minutes with the absorbance of 1,293 and the desirability value of 0.825 .
\end{abstract}

Keyword : Optimization, protoporphyrin IX, quail eggshell

\begin{abstract}
Abstrak
Tujuan dari penelitian ini untuk mencari kondisi optimal dalam kompleksasi Zn(II) dengan protoporfirin IX yang merupakan pigmen pewarna alami pada kerabang telur puyuh. Konsentrasi ekstrak protoporfirin IX sebesar $0,01 \%(\mathrm{~b} / \mathrm{b})$ dari ekstrak kering. Hasil dari kompleksasi tersebut dianalisa menggunakan Response Surface Methodology (RSM). Desain yang digunakan adalah central composite design dengan 3 peubah faktor yaitu $X_{1}=\mathrm{pH}(2 ; 4 ; 6), \quad X_{2}=\operatorname{rasio}(1: 3,1: 4,1: 5)$ dan $X_{3}=$ waktu$\left(30^{\prime}, 60^{\prime}, 90^{\prime}\right)$. Permodelan yang digunakan adalah linear dan menunjukkan bahwa faktor $\mathrm{pH}$, rasio, dan waktu memiliki pengaruh dalam kompleksasi. Permodelan ini memberikan persamaan absorbansi $\mathrm{Y}=2.12506-0.049856 \mathrm{X}_{1}-020316 \mathrm{X}_{2}-0,00409857 \mathrm{X}_{3}$ dan memberikan perlakuan dalam kompleksasi paling optimum yaitu $\mathrm{pH} 2$; rasio 1:3; dan waktu selama 30 menit dengan hasil absorbansi 1.293 dan nilai desirability sebesar 0.825
\end{abstract}

Kata kunci : Optimasi, protoporfirin IX, kerabang telur puyuh

\section{Pendahuluan}

Pewarna memiliki peranan yang penting dalam berbagai industri seperti industri makanan, kosmetik, dan tekstil.
Pewarna tersebut berfungsi untuk mempercantik penampilan dari produk yang dihasilkan. Pewarna yang digunakan pada industri dapat 
dikelompokan menjadi 2 jenis yaitu pewarna alami dan pewarna sintetis. Pewarna alami dapat diperoleh berupa pigmen dari tanaman ataupun hewan. Pewarna alami memiliki beberapa sifat yang menguntungkan yaitu tidak memberikan efek alergi, tidak beracun bagi tubuh manusia, tidak bersifat karsinogenik dan tidak berbahaya bagi lingkungan (Moiz et al., 2010).

Dalam industri tekstil biasanya menggunakan pewarna sintetis karena pewarna sintetis mudah didapat, praktis dalam penggunaan dengan warna yang tidak terbatas (Failisnur dan Sofyan, 2014). Walaupun pewarna sintetis biasa digunakan pada industri tekstil, permintaan pasar akan pewarna alami juga mengalami peningkatan. Permintaan global untuk pewarna alami di seluruh dunia adalah sekitar 10.000 ton, yang setara dengan $1 \%$ dari konsumsi pewarna sintetis di dunia (Sivakumar, Vijaeeswarri and Anna, 2011). Hal ini dikarenakan pewarna alami memiliki sifat tidak beracun dan ecofriendly dan penggunaannya pada industri tekstil memiliki peranan yang penting dalam meningkatkan kesadaran lingkungan untuk menghindari pewarna sintetis yang berbahaya (Mongkholrattanasit et al., 2009).
Salah satu sumber pewarna yang dapat dimanfaatkan adalah dari kerabang telur. Pigmen yang terdapat pada kerabang telur adalah porfirin. Porfirin adalah senyawa makromolekur dengan struktur heterosiklik yang dibentuk 4 buah pyrrole dan disambung dengan jembatan methylene; senyawa ini dapat bergabung dengan ion logam untuk menghasilkan logam porfirin (Wang et al., 2016). Porfirin dapat ditemukan pada telur yang berwarna coklat. Telur dengan warna tersebut mengandung turunan dari porfirin yaitu protoporfirin IX dengan jumlah yang banyak (Zhao et al., 2006). Protoporfirin IX dapat ditemukan juga pada kerabang telur puyuh karena memiliki bercak coklat yang banyak sekali daripada telur yang lain. Kerabang telur puyuh dapat ditemukan pada rumah makan, industri rumahan sate telur, maupun pedagang telur puyuh yang ada dipasar tradisional karena menjadi sampah yang tidak dimanfaatkan ulang, hanya dibuang begitu saja. Mayoritas pewarna alami membutuhkan mordan, yaitu sebuah logam dalam bentuk garamnya yang menciptakan suatu ikatan koordinasi. Penambahan mordan berguna sebagai pengikat antara serat dan pewarna atau molekul pigmen pewarna alami (Samanta and Konar, 2011). 
Penelitian ini menggunakan ion $\mathrm{Zn}$ (II) sebagai logam dalam kompleksasi, walaupun dalam bentuk logamnya $\mathrm{Zn}$ memiliki konfigurasi elektron $[\mathrm{Ar}] \quad 4 \mathrm{~s}^{2} \quad 3 \mathrm{~d}^{10}$ dan sering dianggap sebagai bukan logam transisi namun masih dapat membentuk suatu senyawa kompleks, seperti pada penelitian (Divittorio et al., 2008) yang mensintesa $\operatorname{zinc}(I I)-\left(2,2^{\prime}-\right.$ dipicolylamine) dan penelitian (Rehman et al., 2011) yang mensintesis senyawa kompleks antara hydrazine yang dimodifikasi dengan logam $\mathrm{Ni}(\mathrm{II})$, $\mathrm{Cu}(\mathrm{II})$, dan $\mathrm{Zn}(\mathrm{II})$. Tujuan dari penelitian ini untuk mendapatkan rendemen ekstrak Protoporfirin IX, mendapatkan puncak serapan pada kompleksasi $\mathrm{Zn}(\mathrm{II})$-Protoporfirin IX dan mendapatkan perlakuan yang memberikan hasil yang optimal dalam reaksi kompleksasi Zn(II)-Protoporfirin IX.

\section{Metode Penelitian}

\section{Waktu dan Tempat Penelitian}

Penelitian ini dilaksanakan pada bulan Oktober - Desember 2017 di Laboratorium Kimia, Fakultas Sains dan Matematika, Universitas Kristen Satya Wacana.

\section{Bahan dan Piranti}

Sampel limbah kerabang telur puyuh diperoleh dari pedagang di Pasar
Salatiga. Bahan yang digunakan meliputi $\mathrm{HCl}$, Metanol, $\mathrm{ZnSO}_{4} \cdot 6 \mathrm{H}_{2} \mathrm{O}$, dan larutan ammonium asetat. Semua bahan yang digunakan berderajat PA (Pro-Analysis) diperoleh dari E-Merck Germany.

Piranti yang digunakan dalam penelitian ini adalah spektrofotometer UV/Vis (Optizen 2120), neraca dengan ketelitian 0,01 g (Ohaus TAJ601), neraca analitis dengan ketelitian $0,1 \mathrm{mg}$ (Ohaus PA214), pH meter (Hanna HI 9812), rotatory evaporator (Buchi R114), serta seperangkat piranti gelas.

\section{Preparasi Sampel (Kombado,} Kristijanto and Hastuti, 2014)

Kerabang telur puyuh dicuci dan dikeringkan di dalam drying cabinet selama 24 jam. Setelah kering sampel dihaluskan dan kemudian diayak dengan ayakan ukuran 20 mesh.

\section{Ekstraksi Protoporfirin IX (Wang et} $a l ., 2007$ yang dimodifikasi)

Serbuk kerabang telur seberat 50,00 g dicampur dengan metanol 96\% yang mengandung $\mathrm{HCl}_{(\mathrm{p})}$ dengan perbandingan metanol dan $\mathrm{HCl}$ sebesar 2:1 (v/v). Maserasi dilakukan secara bertingkat dengan waktu perendaman selama satu jam pada suhu ruang dengan menggunakan shaker. Maserasi dilakukan hingga semua Protoporfirin IX telah terekstrak. Perbandingan yang 
digunakan antara sampel dan pelarut dari setiap maserasi adalah $1: 10\left({ }^{\mathrm{w}} / \mathrm{v}\right)$.

\section{Kompleksasi $\quad Z n(I I)(P r a n t i s a$, \\ Martono and Riyanto, 2017 yang dimodifikasi)}

Kompleks Zn-Protoporfirin IX dibuat dengan cara mereaksikan ion $\mathrm{Zn}$ (II) dan ekstrak Protoporfirin IX dengan perbandingan mol 1:3; 1:4; dan 1:5. pH dari ekstrak Protoporfirin IX diatur menjadi 2; 4; dan 6 dengan menambahkan larutan $\mathrm{HCl}$ atau ammonium asetat. Reaksi dilakukan didalam labu dan direfluks dengan variasi waktu 30 menit; 60 menit; dan 90 menit. Sebagai kontrol adalah larutan $\mathrm{Zn}(\mathrm{II})$ dan ekstrak Protoporfirin IX kerabang telur puyuh. Analisa pembentukan kompleks ZnProtoporfirin IX berdasarkan pemindaian dengan alat spektrofotometri UV/Vis pada kisaran panjang gelombang 300-700 nm.

\section{Analisa Data (Heleno et al., 2016)}

Optimasi reaksi kompleksasi dilakukan dengan metode Response Surface Methodology (RSM). Desain optimasi menggunakan model $3^{3}$ central composite design dengan tiga variabel dan tiga level faktor. Sebagai variabel yaitu $\mathrm{pH}\left(\mathrm{X}_{1}\right)$, rasio larutan $\mathrm{Zn}$ (II) dengan ekstrak porfirin kerabang telur puyuh $\left(\mathrm{X}_{2}\right)$, dan suhu reaksi $\left(\mathrm{X}_{3}\right)$. Faktor $\mathrm{X}_{1}$ meliputi $\mathrm{pH} 2$; 4; dan 6 . Faktor $\mathrm{X}_{2}$ meliputi rasio larutan logam $\mathrm{Zn}$ (II) dan ekstrak porfirin kerabang telur puyuh 1:3; 1:4; dan 1:5 (mol/mol). Faktor $\mathrm{X}_{3}$ meliputi waktu reaksi 30; 60; dan 90 menit.

\section{Hasil Dan Pembahasan}

Spektra Protoporfirin IX dan Kompleks Zn-Protoporfirin IX

Kerabang telur puyuh yang dicuci, diekstrak menggunakan pelarut metanol dan $\mathrm{HCl}$. $\mathrm{HCl}$ berfungsi sebagai penghancur kerabang telur yang komponen utamanya adalah kalsium sehingga Protoporfirin IX dapat terekstrak baik di dalam pelarut. Selain itu, $\mathrm{HCl}$ menjadi komponen yang penting dalam proses demetalisasi sehingga protoporfirin IX dapat memutuskan ikatannya dengan ion logam yang ada sehingga dapat terekstrak dalam bentuk Protoporfirin IX saja (Gorchein, Lim and Cassey, 2009).

Protoporfirin IX yang didapat dari hasil ekstraksi memiliki konsentrasi sebesar $0,01 \%(\mathrm{~b} / \mathrm{b})$ dari ekstrak kering. Protoporfirin IX yang diapat dianalisa menggunakan spektrofotometer UV/Vis pada kisaran panjang gelombang 300$700 \mathrm{~nm}$. Hasil spektra dari Protoporfirin 
IX hasil ekstraksi dapat dilihat pada

\section{Gambar 1.}

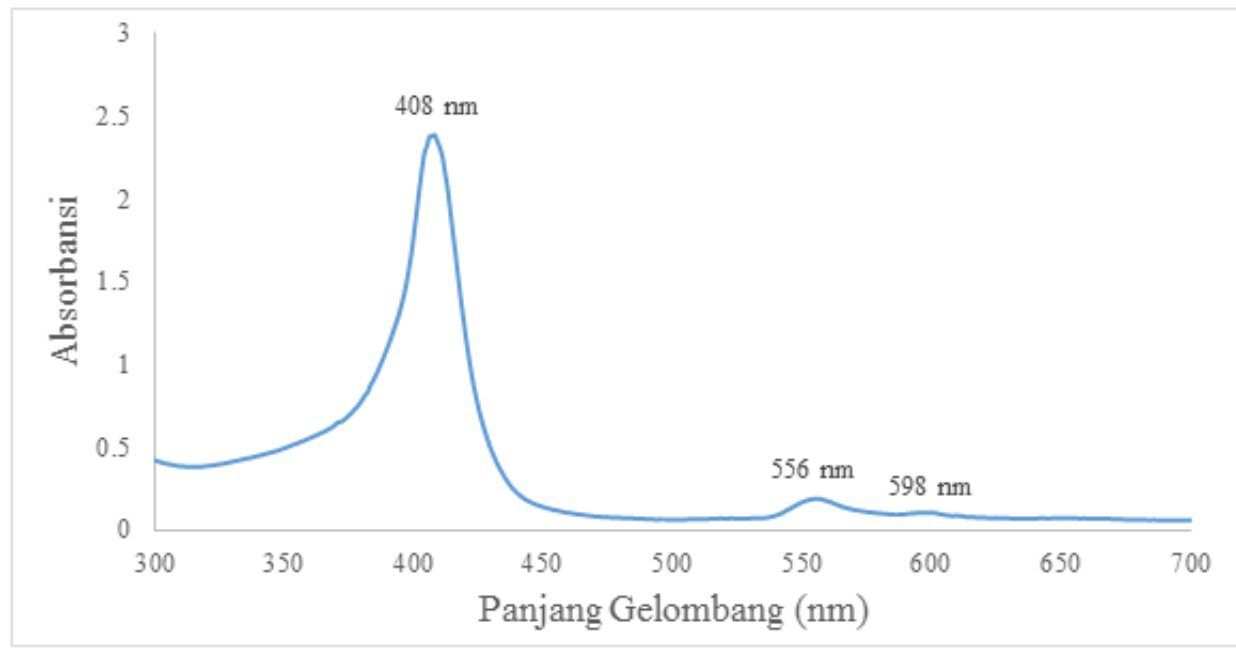

Gambar 1. Spektra Protoporfirin IX

Dari Gambar 1 terlihat adanya puncak utama (Soret) pada panjang gelombang $408 \mathrm{~nm}$ dan dua puncak pendamping (Q-band) pada panjang gelombang $556 \mathrm{~nm}$ dan $598 \mathrm{~nm}$. Beberapa penelitian yang mirip seperti penelitian (Fagadar-Cosma et al., 2014) memiliki spektra 5-(4-pyridyl)10,15,20-tris(3,4-dimethoxyphenyl)porphyrin dengan puncak Soret pada
$423 \mathrm{~nm}$ dan $Q$-band pada panjang gelombang 516, 553, 593 dan $650 \mathrm{~nm}$. Perbedaan puncak Soret dan Q-band ini dikarenakan subtituen pada cicin pirol yang berbeda. Namun perbedaan ini masih dapat ditoleransi, karena porfirin pada umumnya memiliki puncak Soret pada kisaran 400 - $450 \mathrm{~nm}$ dan puncak Q-band pada kisaran 500 $700 \mathrm{~nm}$ (Gottfried, 2015).

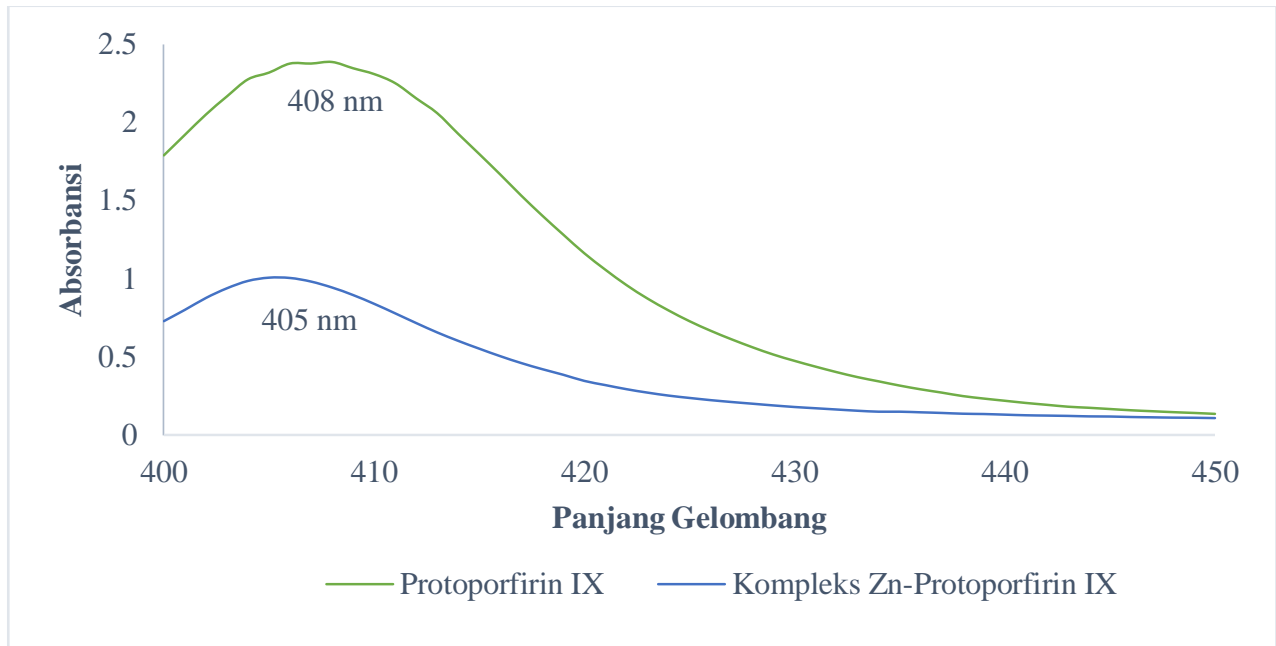

Ekstraksi Protoporfirin IX dari Kerabang Telur Puyuh (Cortunix cortunix) dan Kompleksasinya dengan Zn(II) 
Gambar 2. Puncak Protoporfirin IX dan Zn-Protoporfirin IX

Ekstraksi Protoporfirin IX dari Kerabang Telur Puyuh (Cortunix cortunix) dan Kompleksasinya dengan Zn(II) 
Tabel 1. Tabel fit of summary pemilihan permodelan paling tepat

\begin{tabular}{lccccc}
\hline Source & $\begin{array}{c}\text { Sequential p- } \\
\text { value }\end{array}$ & $\begin{array}{c}\text { Lack of Fit } \\
\text { p-value }\end{array}$ & $\begin{array}{c}\text { Adjusted } R \text { - } \\
\text { Squared }\end{array}$ & $\begin{array}{c}\text { Predicted } R \text { - } \\
\text { Squared }\end{array}$ & \\
\hline Linear & 0,0000 & 0,0503 & 0,7499 & 0,6267 & Disarankan \\
2FI & 0,2347 & 0,0564 & 0,7756 & 0,4677 & \\
Quadratic & 0,5313 & 0,0397 & 0,7637 & 0,1572 & \\
Cubic & 0,2190 & 0,0276 & 0,8295 & $-6,7936$ & Tidak disarankan \\
\hline
\end{tabular}

Hasil kompleksasi antara protoporfirin IX dan Zn(II) menghasilkan puncak serapan pada panjang gelombang $405 \mathrm{~nm}$ dan dibandingkan dengan puncak serapan Protoporfirin IX, seperti pada Gambar 2. Jika dibandingkan dengan puncak awal Soret Protoporfirin IX yang didapat, terjadi pergeseran sebesar $3 \mathrm{~nm}$ ke kiri dari puncak serapan Protoporfirin IX. Pergeseran ini dapat dikatakan adanya reaksi antara $\mathrm{Zn}(\mathrm{II})$ dan Protoporfirin IX, hal ini didukung oleh penelitian Eiro and Heinonen (2002) yang mensintesis kopigmen antara antosianin dan asam galat dengan memberikan pergeseran sebanyak 2,5 nm. Apakah ada hasil penelitian serupa dengan tren ini??? Sebutkan Pergeseran ini mirip terjadi pada penelitian Heriyanto,dkk.(2009) yang menggantikan logam inti bakterioklorofil yaitu $\mathrm{Mg}$ (II) menjadi $\mathrm{Zn}(\mathrm{II})$, yang memberikan pergeseran puncak soret ke arah kiri. Penelitian yang dilakukan oleh Triyani, dkk.(2013) dalam pembentukan kompleks Ni-EDTA menunjukkan pergeseran puncak $8 \mathrm{~nm}$. Jika dibandingkan dengan pergeseran $8 \mathrm{~nm}$, Zn-Protoporfirin IX masih dapat dikatakan berhasil walau terdapat perbedaan nilai pergeseran sebanyak 5 $\mathrm{nm}$, hal ini disebabkan karena setiap logam membutuhkan energi yang berbeda - beda. Hal ini didukung dengan penelitian (Liao and Scheiner, 2002) yang menunjukkan nilai gap antara HOMO - LUMO Zn-Porfirin $(2,60 \mathrm{eV})$ lebih besar dari Fe-Porfirin $(1,87 \mathrm{eV})$, Co-Porfirin $(2,55 \mathrm{eV}), \mathrm{Ni}-$ Porfirin(2,10 eV), dan Cu-Porfirin(1,75 $\mathrm{eV})$.

\section{Analisa Data RSM}

Hasil absorbansi dari setiap kompleksasi dianalisa menggunakan metode Response Surface Metodology (RSM). Desain yang digunakan adalah $3^{3}$ central composite design dengan tiga peubah faktor. Dari hasil absorbansi yang didapat, dianalisa untuk mencari permodelan yang tepat. Informasi yang Ekstraksi Protoporfirin IX dari Kerabang Telur Puyuh (Cortunix cortunix) dan Kompleksasinya dengan Zn(II) 
menunjukkan analisa permodelan paling tepat disajikan pada Tabel 1.

Dari Tabel 1 dapat diketahui bahwa permodel linear adalah model yang disarankan oleh hasil analisa. Model linear dipilih karena memiliki nilai $\mathrm{p}$ yang terkecil dari pemodelan yang lain, nilai $\mathrm{p}$ dari lack of fit lebih kecil dari 0,10 dan selisih antara adjusted $R$-Squared dan Prediksi $R$ Squared lebih kecil dari 0,2. Pemodelan
2FI, Quadratic, dan Cubic tidak memenuhi syarat karena nilai $\mathrm{p}$ lebih besar daripada model linear dan memiliki selisih antara adjusted $R$ Squared dan Prediksi R-Squared lebih besar dari 0,2. Setelah memperoleh permodelan yang cocok, diperlukan analisa untuk mengetahui faktor mana yang memiliki pengaruh dalam reaksi kompleksasi. Analisa tersebut dapat dilihat pada Tabel 2:

Tabel 2. Dasira permodelan linear

\begin{tabular}{lcccccc}
\hline \multicolumn{1}{c}{ Source } & Df & JK & KT & Nilai F & $\begin{array}{c}\text { Nilai P } \\
\text { Prob }>\text { F }\end{array}$ & \\
\hline Model & 3 & 0,905902 & 0,301967 & 19,98838 & $1,17 \times 10^{-05}$ & Signifikan \\
A-pH & 1 & 0,135784 & 0,135784 & 8,988097 & 0,008515 & \\
B-Rasio & 1 & 0,563656 & 0,563656 & 37,31061 & $1,51 \times 10^{-05}$ & \\
C-Waktu & 1 & 0,206461 & 0,206461 & 13,66643 & 0,001955 & \\
Residual & 16 & 0,241714 & 0,015107 & & & \\
Lack of Fit & 11 & 0,220364 & 0,020033 & 4,691595 & 0,050265 & Tidak Signifikan \\
Pure Error & 5 & 0,02135 & 0,00427 & & & \\
Cor Total & 19 & 1,147616 & & & & \\
\hline
\end{tabular}

Kriteria dari suatu faktor dikatakan berpengaruh apabila memiliki p-value yang lebih kecil dari 0,0500. Berdasarkan Tabel 2 dapat diketahui faktor $\mathrm{pH}$, Rasio, dan waktu memiliki pengaruh dalam reaksi kompleksasi namun tidak terdapat interaksi dari antar faktor. Pernyataan tersebut juga didukung oleh Penelitian yang dilakukan oleh Lestari, Afrida and Sanova (2014) juga menunjukkan Ekstraksi Protoporfirin IX dari Kerabang Telur Puyuh (Cortunix cortunix) dan Kompleksasinya dengan Zn(II)

adanya pengaruh $\mathrm{pH}$ dalam pembentukan kompleks Kadmium (II) dengan kupferon. Penelitian yang dilakukan oleh Pekel and Guven (1999) menunjukkan adanya pengaruh rasio terhadap hasil kompleksasi antara poly(N-vinyl imidazole) dengan berbagai ion logam. Sifat dari ligan juga dapat dapat mempengaruhi laju reaksi (Atkins et al., 2009), sehingga waktu reaksi sangat perlu untuk diamati. Yang (A. Rindang Anggit Laksono, Yohanes Martono, Cucun Alep Riyanto) 
harus diperhatikan selanjutnya adalah nilai lack of fit yang menunjukkan data yang diperoleh apakah sudah cocok dengan permodelan yang digunakan. Nilai $p$ value dari lack of fit lebih besar dari 0,05 yang berarti non signifikan, sehingga data aktual dan data hasil permodelan tidak menunjukkan perbedaan yang signifikan. Permodelan ini dapat memprediksi nilai absorbansi dari kombinasi setiap perlakuan dalam reaksi kompleksasi dengan memberikan suatu persamaan sebagai berikut:

$Y=2,12506-0.049856 X_{1}-0.20316 X_{2}-0.00409847 X_{3}$

Dari persamaan (1) diatas dapat digunakan untuk memprediksi absorbansi untuk setiap perlakuan dengan cara memasukkan nilai setiap
$\mathrm{pH}$, rasio, waktu yang digunakan. Penyajian nilai aktual dan nilai prediksi dari absorbansi disajikan pada Tabel 3.

Tabel 3. Nilai aktual dan nilai prediksi absorbansi dari setiap kombinasi perlakuan

\begin{tabular}{llllrr}
\hline \multirow{2}{*}{ Urutan } & pH & \multicolumn{2}{c}{ Rasio } & Waktu & \multicolumn{2}{c}{ Nilai } \\
\cline { 5 - 6 } & & & & Aktual & Prediksi \\
\hline 1 & 2,00 & $1: 3$ & 30,00 & 1,475 & 1,293 \\
2 & 6,00 & $1: 3$ & 90,00 & 0,963 & 0,848 \\
3 & 4,00 & $1: 4$ & 60,00 & 0,829 & 0,867 \\
4 & 4,00 & $1: 4$ & 110,45 & 0,589 & 0,660 \\
5 & 4,00 & $1: 4$ & 9,55 & 1,151 & 1,074 \\
6 & 2,00 & $1: 5$ & 30,00 & 0,723 & 0,887 \\
7 & 4,00 & $1: 4$ & 60,00 & 0,846 & 0,867 \\
8 & 4,00 & $1: 4$ & 60,00 & 0,885 & 0,867 \\
9 & 4,00 & $1: 5,68$ & 60,00 & 0,552 & 0,525 \\
10 & 4,00 & $1: 2,32$ & 60,00 & 1,091 & 1,209 \\
11 & 6,00 & $1: 5$ & 90,00 & 0,637 & 0,441 \\
12 & 2,00 & $1: 3$ & 90,00 & 0,992 & 1,047 \\
13 & 7,36 & $1: 4$ & 60,00 & 0,432 & 0,699 \\
14 & 0,64 & $1: 4$ & 60,00 & 0,967 & 1,035 \\
15 & 4,00 & $1: 4$ & 60,00 & 0,908 & 0,867 \\
16 & 2,00 & $1: 5$ & 90,00 & 0,657 & 0,641 \\
17 & 4,00 & $1: 4$ & 60,00 & 1,008 & 0,867 \\
18 & 6,00 & $1: 3$ & 30,00 & 1,120 & 1,093 \\
19 & 6,00 & $1: 5$ & 30,00 & 0,665 & 0,687 \\
20 & 4,00 & $1: 4$ & 60,00 & 0,852 & 0,867 \\
\hline
\end{tabular}

Nilai absorbansi aktual dan prediksi yang didapat, dapat dibuat menjadi suatu grafik yang membandingkan antar kedua data tersebut. Tujuannya adalah untuk mengetahui sebaran dari setiap data Ekstraksi Protoporfirin IX dari Kerabang Telur Puyuh (Cortunix cortunix) dan Kompleksasinya dengan Zn(II) 
yang ada. Grafik yang menyajikan nilai pada Gambar 3:

aktual vs nilai prediksi dapat dilihat

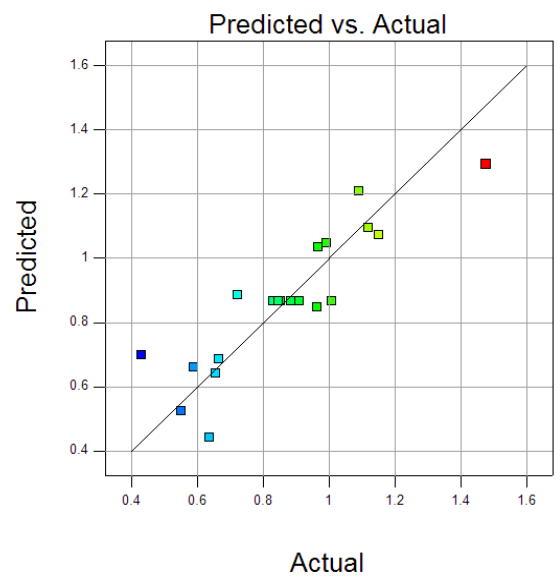

Gambar 3. Grafik nilai aktual vs nilai prediksi

Gambar 3 menghubungkan nilai aktual (sumbu $\mathrm{x}$ ) dan prediksi (sumbu y) untuk menjadi suatu titik yang dipisah oleh garis melintang $45^{\circ}$. Dari Gambar 3 terlihat setiap titik tidak memiliki jarak yang jauh terhadap garis melintang, yang berarti setiap nilai aktual dan nilai prediksi memiliki selisih yang kecil serta sebaran data nilai aktual vs prediksi sudah merata dan tidak memberikan kecenderungan mengelompok dalam satu sisi. Hal ini dapat berarti metode yang digunakan dapat memberikan hasil yang tidak berbeda jauh dengan hasil prediksi.
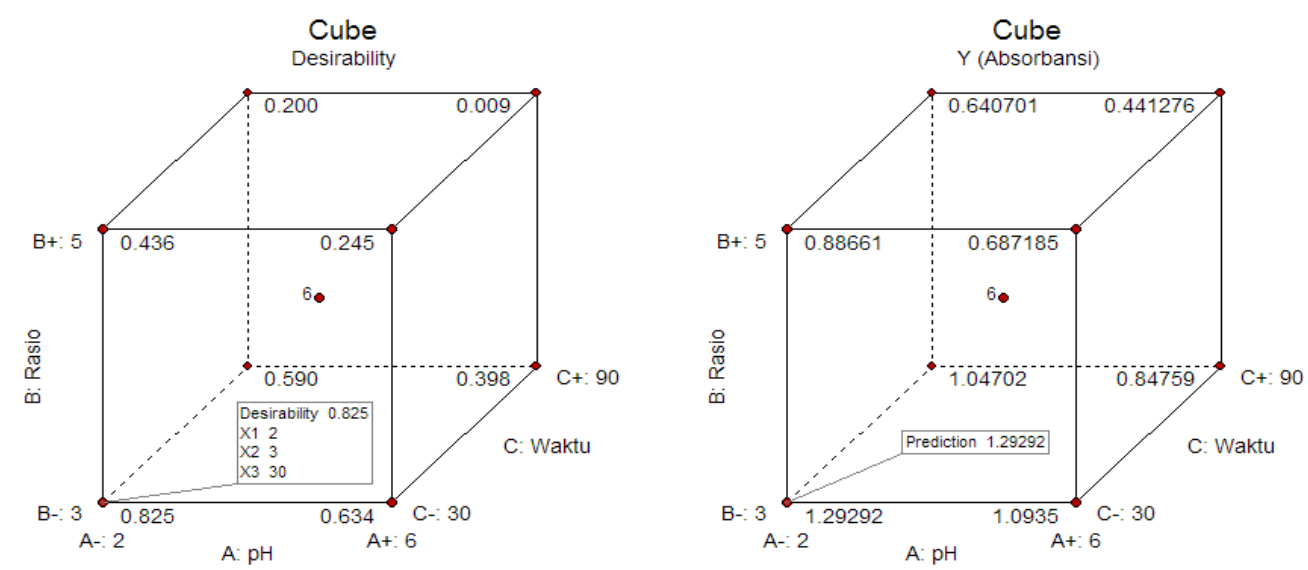

Gambar 4. Grafik Kubus desirability dan nilai prediksi absorbansi 
Penentuan kombinasi perlakuan yang memberi nilai absorbansi tertinggi dapat dilihat pada Gambar 4 dengan cara melihat titik yang menunjukkan desirability terbesar, dalam hal ini titik desirability memiliki nilai sebesar 0,825 menunjuk pada perlakuan $\mathrm{pH} 2$, rasio 1:3, dan waktu 30 menit dengan memberikan prediksi absorbansi terbaik yaitu sebesar 1,29292.

\section{Kesimpulan}

Ekstrak Protoporfirin IX yang didapat dari ekstraksi kerabang telur Atkins, P. et al. (2009) Inorganic Chemistry. 5th edn. New York: W H Freeman and Company. Available at: http://infoscience.epfl.ch/record/25583.

Divittorio, K. M. et al. (2008) 'Zinc ( II ) Coordination Complexes as Membrane-Active Fluorescent Probes and Antibiotics', ChemBioChem, 85287(II), pp. 286-293. doi: 10.1002/cbic. 200700489 .

Eiro, M. J. and Heinonen, M. (2002) 'Anthocyanin color behavior and stability during storage: Effect of intermolecular copigmentation', Journal of Agricultural and Food Chemistry, 50(25), pp. 7461-7466. doi: 10.1021/jf0258306.

Fagadar-Cosma, E. et al. (2014) 'A Sensitive A3B Porphyrin Nanomaterial for CO2 Detection', Molecules, 19(12), pp. 21239-21252. doi: 10.3390/molecules191221239.

Failisnur and Sofyan (2014) 'Sifat Tahan Luntur dan Intensitas Warna Kain Sutera dengan Pewarna Alam Gambir (Uncaria gambir Roxb) pada Kondisi Pencelupan dan Jenis Fiksator yang Berbeda', Jurnal Litbang Industri, 4(1), pp. 1-8. doi: 10.24960/jli.v4i1.634.1-8. 
Gorchein, A., Lim, C. K. and Cassey, P. (2009) 'Extraction and analysis of colourful eggshell pigments using HPLC and HPLC/electrospray ionization tandem mass spectrometry', Biomedical Chromatography, 23(6), pp. 602-606. doi: 10.1002/bmc. 1158 .

Gottfried, J. M. (2015) 'Surface chemistry of porphyrins and phthalocyanines', Surface Science Reports. Elsevier, 70(3), pp. 259-379. doi: 10.1016/j.surfrep.2015.04.001.

Heleno, S. A. et al. (2016) 'Optimization of Microwave-Assisted Extraction of Ergosterol from Agaricus bisporus L. By-Products Using Response Surface Methodology', Food and Bioproducts Processing. Institution of Chemical Engineers, 100, pp. 25-35. doi: 10.1016/j.fbp.2016.06.006.

Heriyanto, Trihandaru, S. and Limantara, L. (2009) 'Keadaan Koordinasi dan Proses Agregasi pada Bakterioklorofil A Serta Turunannya : Studi Pada Pelarut AsetonAir dan Metanol-Air', Indo. J. Chem, 9(1), pp. 113-122.

Kombado, A. R., Kristijanto, A. I. and Hastuti, D. K. A. K. (2014) Limbah Kerabang Telur Puyuh (Cortunix cortunix japonica) sebagai Pewarna Alami Kain Batik (Pengaruh Jenis Fiksatif terhadap Ketuaan dan Ketahanan Luntur. Ditelaah dengan Metode Pengolahan Citra Digital RGB). Salatiga: Universitas Kristen Satya Wacana.

Lestari, I., Afrida and Sanova, A. (2014) 'Sintesis dan Karakterisasi Senyawa Kompleks Logam Kadmium(II) dengan Ligan Kufperon', Jurnal Penelitian Universitas Jambi Seri Sains, 16(1), pp. 01-08.

Liao, M.-S. and Scheiner, S. (2002) 'Electronic structure and bonding in metal porphyrins, metal=Fe, Co, Ni, Cu, Zn', The Journal of Chemical Physics, 117(1), pp. 205-219. doi: 10.1063/1.1480872. 
Moiz, A. et al. (2010) 'Study the Effect of Metal Ion on Wool Fabric Dyeing with Tea as Natural Dye', Journal of Saudi Chemical Society. King Saud University, 14(1), pp. 69-76. doi: 10.1016/j.jscs.2009.12.011.

Mongkholrattanasit, R. et al. (2009) 'Natural Dye from Eucalyptus Leaves and Application for Wool Fabric Dyeing by Using Padding Techniques', Natural Dyes, (September 2017), pp. 57-79. doi: 10.5772/20738.

Pekel, N. and Guven, O. (1999) 'Investigation of complex formation between poly(Nvinyl imidazole) and various metal ions using the molar ratio method', Colloid and Polymer Science, 277(6), pp. 570-573. doi: 10.1007/s003960050426.

Prantisa, D., Martono, Y. and Riyanto, C. A. (2017) Sintesis Pewarna Alami Kerabang Telur Puyuh (Cortunix cortunix) Secara Kompleksasi dengan Ion Cu(II). Salatiga: Universitas Kristen Satya Wacana.

Rehman, S.-U. et al. (2011) 'Synthesis and Characterization of Ni ( II ), Cu ( II ) and Zn ( II ) Tetrahedral Transition Metal Complexes of Modified Hydrazine', J. Mex. Chem. Soc., 55(3), pp. 164-167.

Samanta, A. K. and Konar, A. (2011) 'Dyeing of Textiles with Natural Dyes', Natural Dyes., pp. 29-56. doi: 10.5772/21341.

Sivakumar, V., Vijaeeswarri, J. and Anna, J. L. (2011) 'Effective natural dye extraction from different plant materials using ultrasound', Industrial Crops and Products. Elsevier B.V., 33(1), pp. 116-122. doi: 10.1016/j.indcrop.2010.09.007.

Triyani, N. F., Suhartana and Sriatun (2013) 'Sintesis dan Karakterisasi Kompleks Ni(II)-EDTA dan NI(II)-Sulfanilamid’, Chem Info, 1(1), pp. 354-361. 
Wang, S. et al. (2016) 'Synthesis of Zinc Porphyrins and Effect of Peripheral Substituents on the Coordination Reaction', Indian Journal of Chemistry - Section A Inorganic, Physical, Theoretical and Analytical Chemistry, 55A(2), pp. 145152.

Wang, X.-T. et al. (2007) 'Study of the Deposition Process of Eggshell Pigments Using an Improved Dissolution Method.', Poultry science, 86(10), pp. 2236-2238.

Zhao, R. et al. (2006) 'A Study on Eggshell Pigmentation: Biliverdin in Blue-Shelled Chickens.', Poultry science, pp. 546-549. doi: 10.1093/ps/85.3.546. 